Chen Li-Hong, 2019

Volume 5 Issue 2, pp. 93-102

Date of Publication: 05th August 2019

DOI-https://dx.doi.org/10.20319/pijss.2019.52.93102

This paper can be cited as: Li-Hong, C., (2019). On the Application of Learner-Centered Instruction in the English Pre-Service Teacher Training- A Case from Higher Education in China. PEOPLE: International Journal of Social Sciences, 5(2), 93-102.

This work is licensed under the Creative Commons Attribution-Non Commercial 4.0 International License. To view a copy of this license, visit http://creativecommons.org/licenses/by-nc/4.0/ or send a letter to Creative Commons, PO Box 1866, Mountain View, CA 94042, USA.

\title{
ON THE APPLICATION OF LEARNER-CENTERED INSTRUCTION IN THE ENGLISH PRE-SERVICE TEACHER TRAINING- A CASE FROM HIGHER EDUCATION IN CHINA
}

\author{
Chen Li-Hong \\ School of Foreign Studies, Guangzhou University, Guangzhou, Guangdong Province, China \\ chenlhgz@163.com
}

\begin{abstract}
To discuss the way of applying learner-centered instruction in English pre-service teacher training, a case from higher education in China is analyzed. The main analysis concentrates on course learning, which includes task-based learning, problem-based learning, cooperative learning, inquiry learning, case-based learning, self-directed learning. The author presents some theoretical background of the above ways of learning and uses some examples to illustrate the above methods. The last part is a brief review of learner-centered assignment, assessment, educational practice and the reflection on the learner-centered instruction in the training.
\end{abstract}

Keywords

Learned-Centered Learning, English Pre-Service Teacher, Instruction, Course Learning

\section{Introduction}

In the context of higher education in China, there are different majors related to the teaching profession, such as Chinese Education, English Education, Mathematics Education, etc. Students of different majors must complete different courses and educational practice when they are in universities, which is equivalent to the training for pre-service teachers. For example, if a student 
gets a bachelor degree in English education and English teacher certification for elementary or secondary schools, she/he qualifies to apply the vacancy to be an English teacher. In the article, to make readers better understand, the author uses the term pre-service teacher instead of the students mentioned above.

\section{Learner-Centered Learning}

Learner-centered learning, also known as student-centered learning, means the center of teaching and learning shifting from the teacher to students. Hoidn (2017) believes that learnercentered learning stems from constructivism, which places learners at the core of the learning process and encourages participation-oriented teaching and learning practices. Reigeluth, Beatty \& Myers (2017) point out that learner-centered learning's theoretical foundation's origin from cognitivism, constructivism, and humanism. Among these three theoretical foundations, constructivism is the fundamental one, which can be regarded as the same view as Hoidn's. From the above, the crucial role of constructivism in learner-centered learning is obvious. The constructivism thinks that "learning is a process in which the learner constructs meaning based on his/her own experiences and what he/she already knows" (Wang, 2006:6) and this notion becomes the guideline for learner-centered instruction.

Reigeluth et al. (2017) propose five foundational educational principles or guidance for learner-centered learning, which has attainment-based instruction, task-centered instruction, personalized instruction, changed roles and changed curriculum. These five principles involve the roles of teacher and learner, instruction, and curriculum. Being different from traditional teaching, teachers in learner-centered learning do not play the role of transferring knowledge anymore. Learner-center teachers should "keep the attention, focus and spotlight aimed at and on "the learning process" (Weimer, 2002:76, quoted from Byrne, 2016:11). Their roles change into guiders, helper, etc. along the learners through the learning process. The learner-centered learners are not the passive learners in the non-traditional learning mode, Hannafin \& Hannafin (2010) believe that learners' interests are primary, and their voice is central to the learning experience, so they become the essential role in learner-centered learning.

\section{The Research Question and Method}

The author and her colleagues' (referring to the instructor/s in the article) are responsible for the teaching of the English pre-service teachers in a university in China. Learner-centered 
learning has been applied in different level's teaching and education. The instructors raise the question "How can learner-centered instruction be involved in the pre-service teacher's training"? Therefore, in order to figure out the question, the main method applied in the study is case analysis which is based on the teaching experience of the instructors in a university in China. As referring to the training, the main forms of training for pre-service teachers in higher education in China are course learning and educational practice. The English pre-service teachers take different courses in the university, and the course learning discussed here refers to the specialized courses they take, which relates to English language teaching, such as, English Classroom Language, English Teaching Skills and Practice, National English Curriculum and English Textbooks Analysis, A Course in English Language Teaching, Second Language Acquisition, etc.

\section{Case Analysis of Learner-Centered Instruction on Course Learning}

According to the above guidelines, the instructors apply different instructions in the two perspectives of the training for the English pre-service teachers. The instructors first applies the learner-centered learning on course learning which includes task-based learning, problem-based learning, cooperative learning, inquiry learning, case-based learning, self-directed learning. The summary part includes learner-centered assignment, assessment and the brief description of educational practice in the learner-centered instruction context and the reflection on the whole training. 


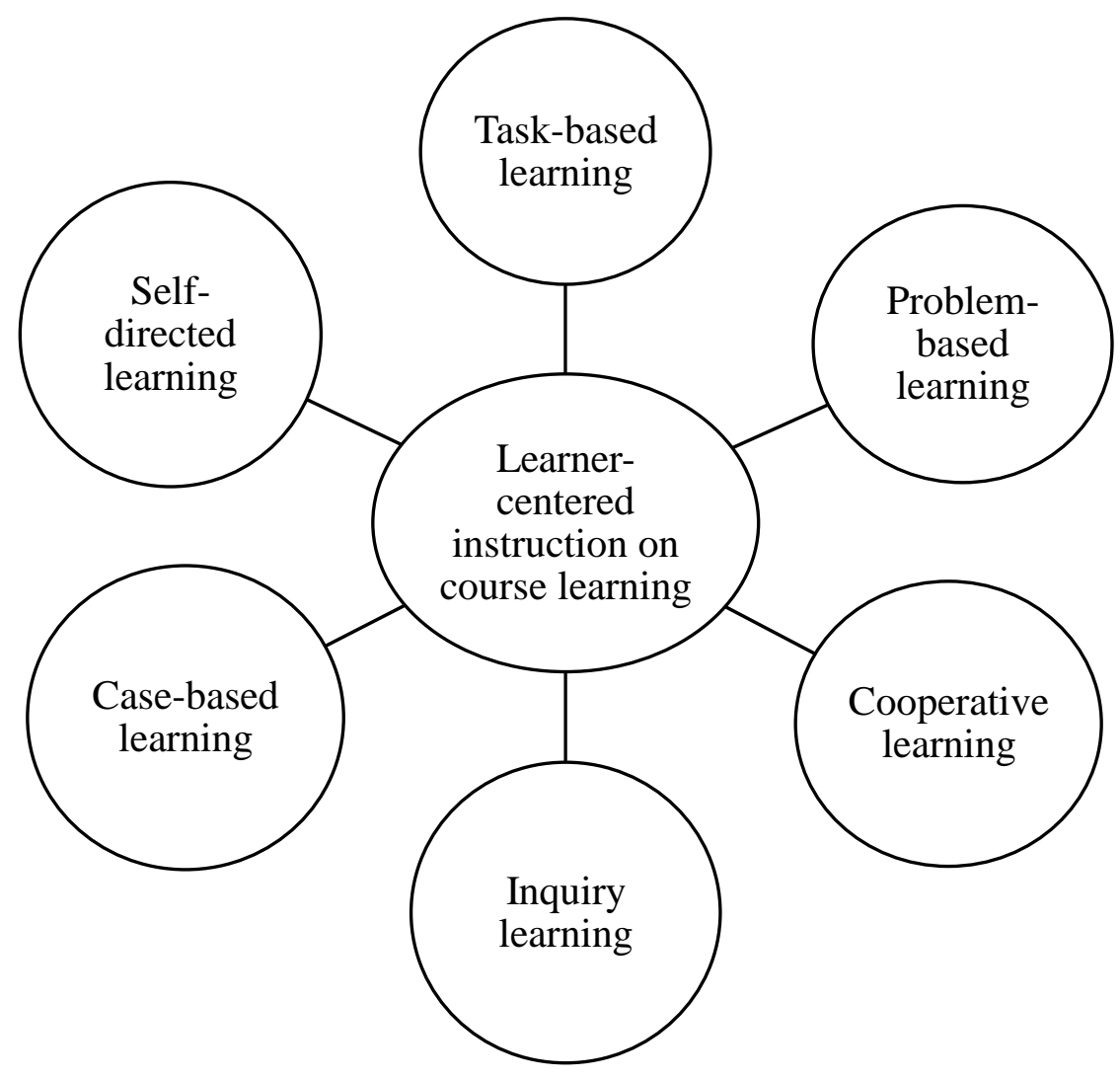

Figure 1: Learner-Centered Instruction on Course Learning

\subsection{Task-Based Learning}

Regarding learner-centered instruction, Reigeluth et al. (2017) recommend that learners should construct knowledge through the engagement in the real-world task and meaningful conversation around the task. From this viewpoint, setting tasks in learner-centered education is significant. For this reason, the instructors employ task-based learning to plan the course learning schedule. For task-based learning, there are mainly pedagogical tasks and real-world tasks (Nunan, 2011:1), and the instructors use both of them in the training. Taking some theoretical knowledge learning as an example, the instructors mainly adopt pedagogical learning, such as, writing a short essay, doing an oral presentation, etc.

In the training, real-world tasks are not only used for assignments but also in-session activities. The English pre-service teachers have different opportunities to get in touch with the tasks linked to their future role, namely English teacher. For instance, the instructor asks a preservice teacher to design a game for teaching new vocabulary to Year 7 students of secondary school. In the task, she/he should apply what he/she learns about using games in teaching English 
from the course English Teaching Skills and Practice. The task is real-world, as in the future when she/he becomes an English teacher, she/he will have the same situation.

\subsection{Problem-Based Learning}

In problem-based learning, learners will face with an 'open-ended, unstructured, authentic (real-world) problem' (Prince \& Felder, 2006:128-129) and they should solve the problem with what they learn. By doing this, the instructors act as facilitators and learners should learn actively (Larsson, 2001:2; Prince \& Felder, 2006:128-129). Accordingly, by applying problem-based learning, learners can:

- Construct an extensive and flexible knowledge base,

- Develop effective problem-solving skills,

- Develop self-directed, lifelong learning skills,

- Become effective collaborators,

- Become intrinsically motivated to learn (Hmelo-Silver, 2004:240).

In the following, the instructors will show examples according to the Hmelo-Silver's (2004) learning cycle. First, the English pre-service teachers should divide themselves into several groups; second, the instructor will present a problem scenario to them; third, they apply what they have learned to solve the problem. In more detail, such as, for the course Classroom Management, after the English pre-service teachers learn the related knowledge, the instructor will set the problembased learning. First, the instructor chooses a central principle-How to deal with an incident in class? Second, the instructor designs a real-world situation for the central principle and develops a case for the English pre-service teachers to solve the problem. Third, the English pre-service teachers apply the theoretical knowledge they learn to solve the problem "How to deal with an incident in class?"

\subsection{Cooperative Learning}

Cooperative learning is based on group work and learners work together and it can make all the group members' learning meet the greatest. To be cooperative, five essential elements need to be carefully structured: "positive interdependence, individual and group accountability, promotive interaction, appropriate use of social skills, and group processing" (Johnson \& Johnson, 1989, 2005, quoted from www.co-operation.org). Taking the five elements as the guideline, the instructors can structure part of the courses cooperatively, design cooperative learning activities to specific course contents, and recognize the problems that the English pre-service teachers may have in group work and improve their group performance. 
In the training, the instructors mainly use team-based learning, project-based learning, collaborative thinking, peer-to-peer interaction, etc. Regarding team-based learning, the English pre-service teachers are grouped of 3-4 persons in different courses, and they will sit with their teammates to learn and finish different tasks during or after the course leaning together. They are also encouraged to involve in collaborative thinking and peer-to-peer interaction during or after course session.

\subsection{Self-Directed Learning}

Self-directed learning refers to "individuals take the initiative, with or without the help of others, in diagnosing their learning needs, formulating learning goals, identifying human and material resources for learning, choosing and implementing appropriate learning strategies, and evaluating learning outcomes" (Knowles, 1975:18, quoted from Scott, 2006:2). Autonomy plays an essential role in self-directed learning, (Song and Hill, 2007:28), and learners are responsible for their own learning and not responding to the instructors (Scott, 2006:10).

In the training, due to limited course time, the English pre-service teachers should carry out self-directed learning to complete some tasks based on some in-session guidance. For example, after being offered some guidance, the English pre-service teachers learn how to design Power Points for teaching young children or teenagers, or the instructor gives them some guidance or suggestions on using stick figures to teach English, and they learn stick figures by themselves. Also, English pre-service teachers keep online learning to enrich their specialized knowledge and educational skills. They take different online courses they need from the Internet, such as Coursera, MOOCs in China, etc.

\subsection{Inquiry Learning}

In inquiry learning, learners answer questions, solve problems or explain observations. The method can help learners "formulate good questions, identify and collect appropriate evidence, present results systematically, analyze and interpret results, formulate conclusions, and evaluate the worth and importance of those conclusions" (Prince and Felder, 2006:127). The two researcher suggest that there are mainly three types of inquiry learning, structured inquiry (learners are given a problem and an outline for how to solve it), guided inquiry (learners must also figure out the solution method) and open inquiry (learners must formulate the problem for themselves) (Prince and Felder, 2006:127).

Referring to structure inquiry, for example, the instructor will offer the English pre-service teachers a question, and they should to work out the answer for the question and not getting 
answers from the instructors. For guided inquiry, for instance, when the English pre-service teachers learn the Communicative Language Teaching method, the instructor does not give concrete definition or principles of it but show a variety of examples. The examples are about different teachers' experiences of using Communicative Language Teaching method. As they see how the teachers apply Communicative Language Teaching, they can figure out how it works in English language teaching, and summarize some theoretical guidelines than being told by the instructor.

\subsection{Case-Based Learning}

According to Prince and Felder (2006:132), a case might include "descriptions of what happened and what led up to it, the problems and challenges, the resources and constraints under which solutions could be sought, the decisions that were made, the actions that were taken, and the outcomes". Through case-based learning, learners should develop theoretical and practical knowledge of their majors, critical reasoning skills, patterns of thinking, etc.

In the training, cases mainly relate to English teaching lessons that primary or secondary school teachers design, such as teaching planning, the video of an English lesson, etc. When English pre-service teachers learn different lesson types, teaching pronunciation, vocabulary, grammar, listening, speaking, reading, and writing, etc., if they only learn the theories or knowledge from the course work, they will not have a deep understanding and cannot apply the knowledge well. Therefore, the instructor will offer the English pre-service teachers some teaching cases and ask them to observe and analyze teaching objectives, teaching focus and difficulty, teaching procedure, etc., and some related theories. After the observation of the concrete cases, the English pre-service teachers can first imitate and improve their own teaching or teaching designing.

\subsection{Learner-Centered Assignments, Assessment and Educational Practice}

Apart from the in-session learning, the after-on assignments are also planned based on learner-centered instruction, which includes individual work and group work. The assignments set for the English pre-service teachers are also based on their learning interests, abilities and learning styles, which corresponds to the belief of learner-centered learning. Apart from some regular assignments, namely oral presentation, writing course essays, etc., the instructor arranges some learner-centered assignments which can arouse the English pre-service teachers' creativity, imagination and also improve their critical thinking ability. For example, after learning English Textbook Analysis, one of the assignments for the English pre-service teachers is to design their own English textbook for specific teaching targets, which can exam what they have gained from 
the course and show their ability on applying what they learn into practice.

To check the result of training, formative assessment and summative assessment are both applied for different courses, which first take the English pre-service teachers' perspective as the priority. The formative assessment may cover the English pre-service teachers' daily performance, involvement, and contribution in the course session, the degree of completing required tasks or assignments, etc.

In the training, for summative assessment, the instructors mainly apply paper examination, however, even for paper examination, learner-centered instruction is also applied. Normal item types in the traditional paper examinations for English pre-service teachers comprise filling blanks, true or false, multiple choice, terms definition, answering questions, etc. However, when the instructors design paper examination, together with a few normal item types, they also consider the English pre-service teachers' learning interest, capacity, learning styles and what skills or ability they need indeed in the future teaching. Therefore, the instructors design some unique item types, like:

- The examiners should analyze an extract of English textbook, and write down the designing purposes of the textbook,

- The examiners will see the transcript of an English teacher's classroom language, they should evaluate whether the teacher's language is proper or not and give reasons,

- The examiners will get a reading passage for Year 8 students, and they should analyze the text by using mind mapping, flow charts, tables, etc.

Along with course learning, the English pre-service teachers must finish different practice which lasts from 1 week to 1 semester, namely educational probation and educational practice. Within the process of practice, the English pre-service teachers should be active and finish their tasks in autonomy.

\section{Conclusion}

In order to find out how learner-centered instruction can be involved in the English preservice training, the author analyzes the case of course learning in higher education context in China by using the following methods, namely, task-based learning, problem-based learning, cooperative learning, inductive teaching and learning, self-directed. According to the effect of the training, the instructors find that:

Though the instructors apply learner-centered instruction in the training for the English 
pre-service teachers, there are some limitations. As some learner-centered learning researchers suggest that in the learning process, learners can select the learning contents, learning methods and the way they assess their own learning (Hannafin, \& Hannafin, 2010). However, in the training, the instruction cannot exactly meet the suggestion and this is what the instructors need to improve in the future.

Note: The article is the stage achievement of Higher Education Teaching Research and Reform Project in Guangdong Province of 2017. The project is "A Research on Curriculum Reform of Teacher Education Specialty based on Career EDGE Employability Model".

\section{References}

Byrne, L.B. (2016). Learner-Centered Teaching for Environmental and Sustainability Studies. In Loren B. Byrne (Ed.), Learner-Centered Teaching Activities for Environmental and Sustainability Studies (pp.1-30). Springer: Switzerland. https://doi.org/10.1007/978-3$\underline{319-28543-6}$

Hannafin, M. J., \& Hannafin, K. M. (2010). Cognition and student-centered, web-based learning: Issues and implications for research and theory. In Spector, J. M., Ifenthaler, D., Kinshuk, \& Sampson, D. (Eds.), Learning and Instruction in the Digital Age (pp. 11-23). Springer: Boston, MA. https://doi.org/10.1007/978-1-4419-1551-1_2

Hmelo-Silver, C. E. (2004). Problem-Based Learning: What and How Do Students Learn? Educational Psychology Review, 16(3), 235-266. https://doi.org/10.1023/B:EDPR.0000034022.16470.f3

Hoidn, S. (2017). Student-Centered Learning Environments in Higher Education Classrooms. Springer: New York. https://doi.org/10.1057/978-1-349-94941-0

Johnson, D. W. \& Johnson R. T. An Overview of Cooperative Learning. Retrieved January 27, 2019, from http://www.co-operation.org/what-is-cooperative-learning/.

Larsson, J. (2001). Problem-Based Learning: A possible approach to language education? Retrieved February 2, 2019, from http://www.nada.kth.se/ jla/docs/PBL.pdf.

Nunan, D. (2011). Tasked-based Language Teaching. Foreign Language Teaching and Research Press:Beijing.

Prince, M. J., \& Felder, R. M. (2006). Inductive Teaching and Learning Methods: Definitions, Comparisons, and Research Bases. Journal of Engineering Education, April, 123-138. 
https://doi.org/10.1002/j.2168-9830.2006.tb00884.x

Reigeluth, C. M., Myers, R. D. \& Lee, D (2017). The Learner-Centered Paradigm of Education. In Reigeluth, C. M., Beatty, B. J. \& Myers, R. D.(Eds), Instructional-Design Theories and Models, The Learner-Centered Paradigm of Education, Volume IV, 1-21. https://doi.org/10.4324/9781315795478

Scott, K. W. (2006). Self-Directed Learners' Concept of Self as Learner: Congruous Autonomy. In Long, H. B. \& Guglielmino, L. M. (Eds), International Journal of Self-Directed Learning, 3(2), 1-13.

Song, L. \& Hill, J. R. (2007). A Conceptual Model for Understanding Self-Directed Learning in Online Environments. Journal of Interactive Online Learning, 6(1), 27-42.

Wang, Q. (2006). A Course in English Language Teaching. Higher Education Press: Beijing. 